\title{
The Landscape Archaeology of Knettishall Heath, Suffolk and its Implications.
}

\author{
Tom Williamson, School of History, University of East Anglia. \\ John Bumstead, Jayne Frost, Lynsey Owens and Steve Pease, Knettishall Heath Nature \\ Reserve, Suffolk. ${ }^{1}$
}

\begin{abstract}
This paper briefly describes the results of archaeological fieldwork carried out in an area of heathland, currently managed as a nature reserve, in East Anglia. Although the earthworks recorded are for the most part unremarkable, they demonstrate the variety and intensity of human exploitation which shaped this 'traditionally managed' habitat. They also serve to emphasise the extent to which modern conservation management can radically change the long-term character of individual places.
\end{abstract}

Keywords: heaths, nature conservation, ploughing, traditional management, earthworks

\section{Introduction}

Heathland is an important although now relatively rare type of 'semi-natural habitat'. Found in areas of leached acid soils, heaths are open treeless landscapes with a vegetation dominated by heather (Calluna vulgaris and Erica spp.), gorse (Ulex spp.), broom (Cytisus scoparius) and grasses like sheep's fescue (Festuca ovina). Heaths are of considerable significance for nature conservation, and heathland restoration is a major policy aim of Natural England. Heaths provide a key habitat for birds like the stone curlew (Burhinus oedicnemus) and the woodlark (Lullula arborea), as well as for a wide range of invertebrates and important reptiles like the adder (Vipera berus). But, as extensive areas of unploughed ground, they are also an archaeological resource, where early earthworks can often be found in significant numbers (Darvill 1987, 105-16).

Most if not all heaths were created by the over-exploitation of formerly wooded ground, often as early as the bronze age (Groves et al. 2012), but sometimes as late as the seventeenth century (Barnes et al. 2007). Those that survived enclosure and reclamation in the eighteenth and nineteenth centuries often returned to secondary woodland in the twentieth, as the intensity with which they were managed declined. Traditionally, heaths were kept open by intensive grazing, and in some districts they formed part of 'sheep-corn' systems: sheep were fed on them by day, and at night taken to the arable fields and close-folded on the fallows, ensuring a regular transfer of nutrients (Kerridge 1967, 42-7). From the fourteenth century, moreover, some examples were used as commercial rabbit warrens (Sheail 1971, 89-90; Williamson 2007, 100-109). In addition, an open environment was maintained by regular cutting. Bracken (Pteridium aquilinum), heather (Calluna vulgaris and Erica spp.) and gorse (Ulex spp.) were systematically harvested from heaths, partly for thatch, fodder or animal

\footnotetext{
${ }^{1}$ Contact: Tom Williamson: T.Williamson@uea.ac.uk
} 
bedding but mainly as fuel (Webb 1998; Warde and Williamson 2014, 65-6). Heather was removed in the form of turves dug to a depth of at least $2.5 \mathrm{~cm}$, which thus included both the vegetation and a square of combustible roots.

This article shows how traditional techniques of archaeological field survey can throw important light on the character of heaths, thereby illustrating the problems with the assumption that they necessarily represent long-established and stable 'zones of archaeological preservation' (sensu Taylor 1972). It also highlights the character of the transition from managed and intensively exploited landscape to contrived 'wilderness' which has sometimes occurred when heaths have become nature reserves.

\section{Knettishall Heath}

Knettishall Heath is located in the East Anglian Breckland, a district of acid sands and gravels which was once noted for its extensive heaths. These were progressively enclosed and reclaimed in the course of the post-medieval period, and especially during a phase of parliamentary enclosure in the decades either side of 1800: the survivors were mainly planted up by the Forestry Commission in the 1920s and 30s. The local landscape is now largely one of pine plantations and wide arable fields, but large tracts of heathland survive to the north of Thetford, used by the army as a Battle Training Area, while several smaller patches, including Knettishall, are managed as nature reserves, although sometimes in ways that deviate significantly from 'traditional' forms of exploitation.

Historically, the Breckland heaths were sometimes used as commercial rabbit warrens but were more usually grazed by sheep as part of sheep-corn systems, as well as being systematically cut for fuel, fodder and animal bedding. In addition (and in common with many other districts) documentary evidence shows that the line between arable and heath was often blurred by the existence of 'brecks', areas of land ploughed for a few years and then allowed to revert to heath on a regular basis, of outfields which were more sporadically ploughed, and of areas cultivated on a casual basis when grain prices were high (Bailey 1989; Belcher 2013).

Most surviving Breckland heaths overlie sands or gravels above chalk and the western and central sections of Knettishall Heath are in this sense typical: they boast some of the best examples of periglacial 'patterned ground' to be found in East Anglia, where alternating strips of chalky and sandy subsoil, caused by cryoturbation during the last Ice Age, can be picked out as lines of contrasting vegetation. But Knettishall Heath has a more complex geology than many examples, with boulder clay occurring beneath the sands and gravels towards the east, while to the north the nature reserve extends onto peaty soils on the edge of the Little Ouse floodplain which, running east-west, forms the northern edge of the heath. From here the ground rises gently towards the south.

Many heaths retained the status of common land well into the post-medieval period frequently up until the time of parliamentary enclosure - but while Knettishall may well have had that status in the Middle Ages, by the end of the eighteenth century it appears to have been entirely private property, part of the Riddlesworth estate, based on Riddlesworth Hall, which stands less than a kilometre to the north-east on the Norfolk side of the Little Ouse. The earliest surviving large-scale map of the area is the Knettishall tithe map of 1840, which shows the heath as the property of Thomas Thornhill, owner of the Riddlesworth estate, but 
occupied by one Jeremiah Matthew (Bury St Edmunds Record Office 464). The heath was then, as today, shaped like an irregular rectangle, tapering towards the west, but with a large block of land apparently cut out of its south-eastern corner ('A' on Figure 1, top). This was enclosed on two sides by the heath and defined on a third (the south) by the parish boundary with Coney Weston. The Heath was, by 1840, already crossed by the straight, evidently postmedieval public roads which remain in place today. These may have been created during the previous half century as Hodskinson's county map of 1783, surveyed at a scale of 2 miles to the inch, appears to show a rather different arrangement of routeways (Hodskinson 1783). The tithe map shows that in the north-eastern corner of the heath a brickworks had been established and that a number of plantations had been made: 'Heath Cover' (later Heath Covert), a rectangular block of woodland covering some 7 hectares, surrounded on all sides by open heath; 'Nick's Hill Cover' (later 'The Belt'), a narrow strip of trees running along the southern boundary of the heath; 'New Plantation' (later Blackbrake Strip), running along the south-eastern boundary (along the eastern edge of the apparent 'intake'); and an ovoid clump ('Round Cover') on the eastern side of the heath.

The names used by the tithe map are typical of those applied to eighteenth-century plantations in the district, combining as they do a prefix derived from a local place- or fieldname, or a simple descriptor of shape, with the term 'plantation' or 'cover', the latter clearly suggesting a role in game management. None of the Knettishall Heath plantations are shown on Hodskinson's 1783 map and while this is not very reliable evidence (Hodskinson's depiction of woodland is not comprehensive) it is likely that most if not all were planted in the late eighteenth century. In c.1785 the Riddlesworth estate was purchased by the wealthy banker, Sylvanus Bevan, a noted agricultural 'improver' who is referred to on a number of occasions by Arthur Young in his General View of the Agriculture of Norfolk of 1804 (Kenworthy-Brown et al. 1981, 175). According to Young, among his other achievements Bevan planted no less than 966,000 trees on his estate, 'which have, at present, a flourishing appearance' (Young 1804, 383). There seems little doubt that the plantations represent part of this afforestation scheme.

Later maps - successive editions of the Ordnance Survey 6-inch and 25-inch to the mile - show only minor changes to the arrangement of features shown on the tithe map. By the 1880s, to judge from the First Editions of these maps, a further area of woodland had been established, 'The Scotches', running east from New Plantation/Blackbrake Strip (thus forming the northern boundary of the putative 'intake') (Figure 1). Heath Covert and Round Cover remained unchanged, but The Belt had lost its wider, eastern end. These maps, and subsequent editions, also show a few scattered trees on the heath, especially in the vicinity of the plantations: but as late as 1946, to judge from the RAF vertical air photographs, it remained largely open and also largely free of bracken. Only during the second half of the twentieth century, as the intensity of grazing declined, did the area become more infested with bracken and gradually invaded by trees - principally Scots pine, silver birch and oak which spread out from the existing plantations (Figure 2).

In the 1970s Knettishall Heath was leased by Suffolk County Council as a 'country park' and in 2012 it was bought by the Suffolk Wildlife Trust, with Heritage Lottery Fund support, and is now managed as a nature reserve. The extent of scrub and woodland has been significantly reduced in recent years, but both old-established plantations and many areas of 
more recent, secondary woodland have been retained and thinned, and are now managed as wood-pasture - large areas of the reserve are grazed by ponies. In the open areas of the reserve the bracken has been reduced by systematic cutting and chemical treatments, and extensive stands of heather have regenerated. In addition, the characteristic vegetation of heath and 'breck' are encouraged by the creation of 'disturbance areas', where the upper surface layers are stripped away to reveal the mineral soil beneath. The current landscape of Knettishall Heath is thus the consequence of careful management, directed at maximising biodiversity. While the western and northern portions of the reserve remain as open heath, the landscape is significantly more wooded, and has a much more graded transition from woodland to open heath, than was the case half a century ago (Figure 3). The south-western and south-eastern margins - the western end of the Belt, The Scotches, and Brick Kiln Covert - continue to be managed as commercial forestry plantations, and are not under the control of the Wildlife Trust.

A number of archaeological sites and features have long been known on the heath. The two most important monuments are Hut Hill and The Warren. The former is a substantial bronze age round barrow, which was surmounted until recently by a prominent Scots pine, and which was marked and named on the Ordnance Survey 6-inch First Edition of 1885 and photographed by W. G. Clarke for his iconic book, In Breckland Wilds (Clarke 1925). The Warren is more problematic: a circular ditched enclosure containing low, disturbed mounds, it appears to have been identified as a rabbit warren only from the 1990s (Saussams 1996). In addition, finds of Neolithic and bronze age flintwork, and some bronze age pottery, together with some of the earthwork banks mentioned below, are noted in the Suffolk Historic Environment Record.

\section{Military earthworks, pits and tracks}

The most recent earthworks on Knettishall Heath relate to Second World War military activity. Knettishall airfield, used by the USAAF's 388th Bombardment Group (Heavy) from June 1943 until the end of the war (Bowman 2009, 122-27), lies a few hundred metres to the south-east, but these earthworks do not appear to relate to its defence but rather to military training, probably by the Home Guard. Four take the form of roughly square or rhomboid pits, around five or six metres across and around a metre deep, each with a sloping 'entrance' on one side and a low outer bank (Features 'a' - 'd' on Figure 4; see also Figure 5). They appear to be gun pits, for housing light artillery or heavy machine guns. A fifth example (e) is more complex, being approached by a shallow winding trench running at right angles to a separate bank and slight trench. There is also a smaller but related structure with a crossshaped plan (feature 'f'). In addition, several shallow rectangular pits are scattered across the heath, each the size of an individual soldier, one of which has been cut into the side of a possible round barrow (not individually mapped on Figure 4, but see Figure 7, feature ' $u$ ').

Military training in England during the Second World War frequently used poor, marginal land, especially heaths (Liddiard and Simms 2012), and a number of other areas of Breckland, as already noted, were and are used for this purpose. Although many of the Knettishall earthworks are now in woodland, their role as gun emplacements makes it clear (as the 1946 air photos do indeed show) that the landscape was then largely open. In addition to these earthworks, a linear feature running north-south across the heath for some 40 metres 
(figure 4, feature ' $\mathrm{g}$ ') is locally said to be a World War II practice trench, but instead appears to be the working face of a backfilled area of gravel and sand extraction first shown on the Second Edition 6-inch map of 1905.

There are, in fact, a large number of extraction pits on Knettishall Heath. Those towards the eastern side of the heath were mainly dug to provide clay for the brickworks already noted, which was probably established by the end of the eighteenth century, and which continued to function into the twentieth (remains of the nineteenth-century kiln, and other features, can be seen in the base of a large pit, now wooded - ' $h$ ' on Figure 4). Most of the pits are shallow, and presumably partly filled-in; some may represent exploratory excavations. One example clearly pre-dates the establishment of Round Cover plantation in the later eighteenth century, the boundary of which follows its rim. Towards the western side of the heath the pits are more widely scattered and appear mostly to have been dug for sand or gravel, but there are in addition two deep chalk pits: one around 5 metres deep just to the north of the earthwork called The Warren, (Figure 4, feature ' $i$ '); the other a massive 15 metres deep and nearly 30 wide in the northern part of Blackbrake Strip (Figure 4, feature 'j’).

The area where the extraction pits are most common, immediately to the west of the brickworks, is crossed from east to west by traces of roughly parallel tracks (Figure 4, ' $\mathrm{k}$ ', ' 1 '). These take the form of slight depressions or cuttings where the ground is raised up, and in places - of low embankments across filled pits. The tracks can be picked out as slight earthworks right across the heath. To the west, they appear to cross the present public road, one continuing to the north-western corner of the reserve. To the east, they carry on beyond the reserve, across Norwich Lane and through Brickkiln Covert, until the adjacent area of arable is reached. Here they disappear, but seem to be heading for Knettishall parish church, just over a kilometre to the east. The tracks seem unrelated to the modern roads running across the heath and the most southerly can, perhaps, be identified with a road shown on Hodskinson's Suffolk map of 1783.

\section{Banks and cultivation ridges}

There are a number of linear banks on the heath, most of which are of post-medieval date. Some originally enclosed the plantations, although they now often have woodland on both sides due to the expansion of tree cover during the later twentieth century. That associated with Heath Covert (Figure 4, ' $\mathrm{m}$ ') is substantial, between three and four metres in width and rising in places to a height of three quarters of a metre, perhaps because of the need to protect the young trees from rabbits; it was presumably once topped with a line of gorse, as advocated by the agent for the Walsingham estate, on the eastern edge of Breckland, in 1851 (Norfolk Record Office WLS XVIII/7/1). Within the area it encloses (amongst more recent planting) a scatter of beech trees survives; they have girths of around 3 metres but are almost certainly of nineteenth-century date rather than being original components of the plantation (trees of similar size growing to the south of the plantation do not appear to be shown on the First Edition 6-inch OS, although they can be seen on the RAF vertical photographs of 1946). The northern boundary of The Belt (the southern is marked by the parish boundary) is a bank of similar form, but slightly smaller (Figure 4, ' $n$ '). In this case, the bank is topped in places by a line of oak trees and some of the original eighteenth-century planting survives in the 
form of massive sweet chestnut coppice stools or, more probably, pseudo-coppice - that is, the regenerating stumps of felled timber trees. 'Round Cover' is surrounded by a similar (although much degraded, in part by recent tree felling) bank (Figure 4, 'o').

The boundaries of Blackbrake Strip and The Scotches are different. The latter plantation was established between 1840 and the 1880s and has no perimeter bank. Although it forms the edge of the heath, it was actually planted on what the tithe map shows as an adjoining arable field. Blackbrake Strip, although already in existence by 1840 , is probably in this respect similar. Its original western boundary (Figure 4, 'p') is formed by a prominent earthwork bank around four metres across with a slight ditch to the east, and its northern boundary (' $\mathrm{q}$ ') is comparable, but more degraded. Its southern side however is defined by a less substantial earthwork (' $r$ '), and its eastern edge has no bank at all, merely a slight lynchet. These differences probably indicate that the northern and western banks were not originally the boundaries of the plantation, but instead marked a division between the heath (to the north and west) and arable land (to the south and east), and were thus presumably created when the putative intake was made from the south east of the heath at some unknown date before 1840. It is noticeable that the ground to the west of bank ' $p$ ' appears slightly higher than that to the east, suggesting that the latter has been lowered by plough erosion that is, the bank forms a slight lynchet. The huge chalk pit which exists towards the northern corner of the wood (' $j$ ') may have been excavated to supply marl for this new area of arable land. Blackbrake Strip, like the other plantations, largely comprises relatively recent, probably twentieth-century, oak and sweet chestnut but also includes a few larger sweet chestnut standards, some with girths reaching 3.7 metres, just possibly remnants of the original planting.

The longest of the earthwork banks at Knettishall - Figure 4, feature 's' - runs through the centre of the heath, from the southern edge of The Warren to a point a little to the south of Hut Hill ('t' on Figure 4), where it makes a right-angle turn to the south. Its alignment clearly suggests that both these earthworks were used as markers when it was laid out. West of The Warren the bank appears to change alignment, continuing beside a modern track, in more degraded form, for c.100 metres before disappearing abruptly. The bank is generally around $0.2-0.3$ metres high and 2 - 3 metres wide and in places has a shallow ditch on the southern / western side. Its well-defined character and relatively straight alignment suggests a post-medieval date but it does not appear as a boundary on the 1840 tithe map, or on the various Ordnance Survey maps. Whatever its function, it must predate both the establishment of Blackbrake Strip plantation in the later eighteenth century and the removal of the south-eastern corner of the heath at some earlier date, for where it passes through the former it has been completely levelled, presumably by ploughing, only reappearing intact beyond its western boundary.

Perhaps the most surprising aspect of the heath's field archaeology is the evidence of ploughing which occurs in a number of places. Where the ground cover comprises closecropped turf, rather than heather or bracken, slight ridges, a few centimetres high, can sometimes be seen; while removal of the topsoil in many of the 'disturbance areas' has revealed patterns of dark, parallel lines (Figure 6). Where earthwork ridges are visible adjacent to these stripped areas, the dark bands can be seen to correspond with the 'furrows', filled with dark organic matter. Everywhere the lines and/or ridges appear to share the same 
general orientation, running more or less north-south. While the density of the vegetation makes it impossible to plot the complete distribution of the ploughlines, there is no doubt that they are absent from the western side of the heath and that they are otherwise restricted to the area lying to the south and west of the long bank described in the previous paragraph (Figure 4 , ' $\mathrm{s}$ '). In a number of places they visibly respect the latter, stopping between two and four metres short as if to leave a narrow 'headland'.

In 1908 the Norfolk archaeologist W.G. Clarke described how

'Within the past decade big areas of heath and derelict 'breck' - notably on

Rushford, Knettishall, Snarehill, Melford, Roudham, and West Tofts heaths,

Brettenham Drove, and on the Elveden estate - have been brought under cultivation

by the steam plough' (Clarke 1908, 563),

Bank 's', however, had ceased to be used as a boundary well before the end of the eighteenth century, and would not have presented any barrier to the plough by c.1900. The ridges cannot, therefore, be associated with the steam-ploughing described by Clarke, which almost certainly took place on the western side of the heath - in the area to the west of The Warren where evidence for the plough-ridges is lacking, and where earthworks of any kind are noticeably absent.

The surviving ridging, in contrast, must relate to an earlier phase, presumably (on the basis of its relationship with the bank) pre-dating the later eighteenth century. What remains unclear is its purpose. If created as part of normal agricultural operations the ridges should have been levelled by subsequent harrowing, to produce a level seed bed. They might represent an attempt at cultivation abandoned after the initial ploughing stage, but a more interesting possibility is that they were created at the end of a short period of cultivation, perhaps in order to reduce wind erosion (the lines lie at right angles to the prevailing wind direction). Several accounts of post-medieval legal cases suggest that heathland in Suffolk was often left ridged after periods of temporary arable use. A court held in 1637 thus heard how the demesne farmer of the manor of Blythburgh and Walberswick in east Suffolk:

'Used to plow such parte of the said walke or heath as they would; \& when any part thereof was sowen with corne, the inhabitants of Walberswick did not put their cattle upon such places soe sowen untill the corne was reaped ... And that it appearses by the rigges and furrowes on most parte of the heath, that the same have usually byn ploughed' (Ipswich Record Office HA 30: 50/22/3.1).

Closer to Knettishall, signs of ploughing were similarly used as evidence in a court case relating to land at Brandon Warren in 1612, again using the term 'rigge and furrow' (The National Archives/PRO E134/10Jas/East27). The ridges on Knettishall Heath may thus represent rare archaeological evidence for an agricultural practice once common in East Anglia when temporary intakes were allowed to return to heath following short periods of cultivation.

\section{Prehistoric earthworks}

As noted, Hut Hill ('t' on Figure 4) has long been known as a round barrow. It is a striking feature of the local landscape, over two metres in height and 30 metres in diameter. There are uncertain traces of a wide, filled ditch to north and east. It occupies a prominent position, on a knoll overlooking the valley of the Little Ouse to the north, and was clearly placed to ensure 
that it was visible from lower ground, implying in turn that the surrounding landscape was largely clear of trees when it was constructed. Another known barrow lies within Brickkiln Covert, just outside (to the east of) the Heath, likewise occupying a 'false crest' position. In addition, recent survey work located two new possible examples. One, at TL9493380281 (Feature ' $u$ ', Figures 4 and 7), lies towards the north-eastern corner of Heath Covert. It is just over fifteen metres in diameter and around 0.7 metres in height, and while it lacks an obvious encircling ditch it occupies a 'false crest' position with a commanding view northwards across the Ouse valley. If it is indeed a barrow, it has presumably been partially levelled by the early ploughing just described. The second, around 30 metres across and just over a metre high, lies within Blackbrake Strip plantation at TL9543580035 and has been partly destroyed by the excavation of the deep chalk pit ('j') (Figures 4 and 7, feature ' $v$ '). It is less convincing as a barrow, being slightly irregular in shape, but its current appearance may be the result of the fact that it lay within an area of arable land, rather than heath, before Blackbrake Strip was planted, as described above. It, too, occupies a prominent position, in this case commanding fine views to the south. It is possible that further examples of nearlevelled barrows remain unlocated within the more overgrown areas of the heath.

Also, perhaps, of prehistoric date is the enigmatic feature known as The Warren (Figure 4, feature ' $w$ '), which comprises a circular enclosure c.40 metres across, defined by a ditch some 7 metres wide which is flanked in places by a slight outer bank/scarp (Figure 8). Half of its interior has been quarried away at some date, in places almost to the level of the base of the ditch: some of the material removed was placed in irregular piles on the undisturbed section of the interior. The earthwork has been interpreted as a 'clapper', an enclosure for protecting breeding does in a rabbit warren (Sussams 1996), but examples of such features elsewhere generally take a rectangular or sub-rectangular form and have substantial external banks (Williamson 2007, 71-5). Its identification as an earthwork associated with a warren mainly rests on the fact that rabbit farming was widespread in Breckland (although no evidence of any commercial warren has, it should be emphasised, been discovered in Knettishall) (Mason and Parry 2010). The earthwork is clearly one of the oldest features on the heath, predating the construction of bank 's', which aims for and then swings around it. In spite of a fairly crisp, well-defined profile, it is possibly prehistoric: perhaps the remains of a large bell barrow, although this form of monument is not well represented in East Anglia. Its damaged character makes any interpretation problematic.

Also possibly of prehistoric date is a slight bank between 5 and 6 metres in width but nowhere more than c. $25 \mathrm{~cm}$ high which runs north from The Warren (' $x$ '). It is flanked in places by a slight ditch on its western side (indeed, immediately beside this earthwork it is mainly apparent as a ditch), but this becomes less pronounced moving northwards, eventually disappearing entirely; the bank itself gradually becomes vaguer and more diffuse, and is hardly visible for the last c. 25 metres before the road is reached. Its age and purpose are unclear: there is no sign of it south of the Warren. Its form and condition would seem to preclude a post-medieval or even, perhaps, a medieval date.

\section{Discussion}

In many ways the features briefly described above are unremarkable, but they are typical of those found more widely on heathland across England, constituting in a sense its 
archaeological 'signature'. The physical traces left by military training in World War II, for example, are frequent encountered on heaths; bronze age round barrows are a relatively common monument in such contexts; heaths were often extensively quarried for sand and gravel; and plantations of eighteenth- and nineteenth-century date are characteristic features and were often, as here, protected from rabbits and sheep by substantial perimeter banks.

Yet if unremarkable, these archaeological remains can nevertheless tell us much about the true character of the local landscape. The evidence for extensive ploughing in particular is a reminder that heaths might have been subject to phases of intensive land use in the relatively recent past, and on a considerable scale: they are not necessarily continuous 'zones of preservation' where ancient remains survive intact en masse. On the contrary: the almost invisible condition of the probable but previously unrecorded barrows noted above shows clearly how the plough - that great enemy of the past - has even here been at work. In many areas of heathland, in East Anglia as elsewhere, the current distribution of prehistoric earthworks - that is, of those prominent enough to have been noted by archaeologists and others - will have been similarly structured by later patterns of land use. Other activities characteristic of heaths may also have had an impact on the archaeological record. While the scale of sand, gravel, chalk and clay extraction at Knettishall has evidently been greater than on many heaths, the difference is one of degree. How much of the surface of the heath has been affected by a combination of extraction pits and ploughing is uncertain, but the figure might reasonably be estimated at between 50 and 70 per cent (Figure 9).

The extent and variety of human activities indicated by the archaeological evidence have other, perhaps more interesting implications. As we have emphasised, the position of the bronze age barrows suggests that they were constructed in a landscape which was relatively open, with extended views, and it probably remained that way for more than 3,000 years, until the middle of the last century. Then, however, the area of woodland increased steadily from around 15 per cent in 1946 (the eighteenth- and nineteenth-century plantations) to 40 per cent by 1976, reaching around 65 per cent by 1990. At the same time, bracken expanded at the expense of Calluna and grass. Some attempts were made to check both processes after the heath became a 'country park', and these became more intensive after it acquired its new role as a nature reserve, with large-scale felling of trees and chemical treatment of bracken.

The current management of the area, by the Suffolk Wildlife Trust, is not however directed simply towards the restoration of open heath. Large tracts in the west and north of the reserve especially are being managed to this end, and subject to localised ground disturbance to encourage the key plant specialists of Breckland (Dolman et al. 2010 and 2012). Elsewhere, however, large parts of the reserve - both original plantations, and more recent areas of woodland regeneration - are being thinned and managed as wood-pasture. In part this policy is intended to create a diverse range of habitats, featuring abundant ecotonal transitions; in part it is a recognition of practical realities, of the changed state of the local environment; but in part, perhaps, it shows the influence of Frans Vera's hypothesis that the natural, pre-Neolithic landscapes of western Europe were characterised by fairly open woodland, grazed by large herbivores (Vera 2000). Indeed, in part as a response to the fact that the heath is extensively used by dog-walkers, it is now grazed by a group of ponies, rather than sheep. 
Vera's ideas have been immensely influential in nature conservation circles, especially among advocates of 're-wilding' (Soulé and Noss 1998; Monbiot 2015). Grazed wood-pastures are seen by many as the best model for future wildlife management, preferable in many contexts to the 'traditional' habitats, shaped by centuries of past management, which are usually associated with nature conservation in Britain. But the 'Vera hypothesis' has been increasingly challenged by archaeologists and others (Hodder et al. 2009; Kirby and Baker 2013; Yalden 2013; Samojlik and Kuijper 2013), and it is arguable that the contrived wildness of Knettishall Heath is the manifestation of a fashion, analogous in some ways to the equally contrived, but more manicured, landscape parks created by Capability Brown, likewise described by contemporaries as 'natural' (Brown and Williamson 2016, 155-9, 17880; Williamson 2017).

All this said, current management to maximise environmental diversity and ecotonal complexity is laudable and understandable given the restricted and fragmented character of semi-natural habitats of all kinds in the district. Knettishall Heath, having experienced a short period of neglect and decline in the twentieth century, is now being managed for important new reasons. However, as a consequence it has, in a sense, been removed from Breckland from the landscape of open heaths and 'brecks' which traditionally characterised the district. Indeed, the Suffolk Wildlife Trust openly state their aim of developing the area as the 'New Forest of East Anglia'. Yet it is a curious paradox that, while in a sense taken out of time and out of place, this 'natural' landscape cannot escape the structuring hand of history. The maps produced by Marrs et al. showing the spread of bracken on the heath between 1946 and 1976, based on an examination of aerial photographs, suggest that this occurred more slowly in the southern parts of the heath (the area in which the plough 'ridges' are found) and in the western areas (probably, as noted above, ploughed up in the late nineteenth or early twentieth century) than in the northern parts (Marrs et al. 1986, 23-4). More importantly, wooded ground, although more extensive (and with a more gradual transition to open heath) than a few decades ago, nevertheless remains concentrated in and around the plantations established in the late eighteenth and nineteenth centuries. Conversely, we should note that in the areas of the reserve kept open by cutting and grazing there is now no discernible difference in the vegetation of the areas which, on present evidence, have never been heavily disturbed, and those characterised by former extraction pits or ploughing.

\section{Conclusion}

Knettishall Heath is probably not unusual as a 'semi-natural' habitat in having a history which has been characterised not by stability, but by disturbance and change (Fuller et al. 2016). The current management of the heath, aimed at enhancing biodiversity and the experience of its many visitors, has ensured that it now looks very different from when it was exploited on 'traditional' lines. Its appearance of wilderness is contrived and deceptive: long periods of intensive but varied exploitation separate it from any truly wild landscape. But, in a situation in which wildlife habitats of all kind have become excessively fragmented, designing new landscapes to maximise biological niches is to be welcomed. The Suffolk Wildlife Trust are developing a new, complex ecosystem for conservation, not simply recreating past management practices. To some people such interventions might appear to be producing something which is highly 'unnatural' in character, but the archaeological 
evidence leaves no doubt that the open heath which this landscape has partly replaced was itself subject to complex and far-reaching interventions, albeit ones intended to achieve rather different ends.

\section{Acknowledgement}

The research described here was carried out as part of a larger project, 'Breaking New Ground', which was funded by the HLF (Heritage Lottery Fund). We would like to thank Tim Holt-Wilson, for useful geological advice; and Samantha Gay and Steve Aylward of the Suffolk Wildlife Trust, for their help and encouragement.

\section{References}

Bailey, M. 1989. A Marginal Economy? East Anglian Breckland in the later Middle Ages, Cambridge University Press, Cambridge.

Barnes, G., Dallas, P., Thompson, H., Whyte, N. and Williamson, T. 2007. Heathland and wood pasture in Norfolk: ecology and landscape history. British Wildlife 18, 395-403.

Belcher, J. 2013. "The Chiefest Wealth of Our Country”: The Foldcourse in East Anglia. Unpublished PhD thesis, University of East Anglia.

Bowman, M.W. 2009. Bomber Bases of World War 2: $3^{\text {rd }}$ Air Division, $8^{\text {th }}$ Air Force USAAF 194245. Flying Fortress and Liberator Squadrons in Norfolk and Suffolk, Pen and Sword, Huddersfield.

Brown, D. and Williamson, T, 2016. Lancelot Brown and the Capability Men; landscape revolution in eighteenth-century England, Reaktion Books, London.

Clarke, W.G. 1908. Some Breckland characteristics. Transactions of the Norfolk and Norwich Naturalists' Society 8, 555-78.

Clarke, W.G. 1925. In Breckland Wilds, Heffer, Cambridge.

Darvill, T. 1987. Ancient Monuments in the Countryside: an archaeological management review, English Heritage, London.

Dolman, P.M., Panter, C. and Mossman, H.L. 2010. Securing Biodiversity in Breckland: Guidance for Conservation and Research. First Report of the Breckland Biodiversity Audit. University of East Anglia, Norwich.

Dolman, P. M., Panter, C. J. and Mossman, H. L. 2012. The biodiversity audit approach challenges regional priorities and identifies a mismatch in conservation. Journal of Applied Ecology 49, 986997.

Fuller, R., Williamson, T, Barnes, G. and Dolman, P. 2016. Human activities and biodiversity opportunities in pre-industrial cultural landscapes: relevance to conservation. Journal of Applied Ecology 54, 459-69.

Groves, J.A., Waller, M.P., Grant, M.J. \& Schofield, J.E. 2012. Long-term development of a cultural landscape: The origins and dynamics of lowland heathland in southern England. Vegetation History and Archaeobotany 21, 453-470.

Hodder, K.H., Buckland, P.C., Kirby, K.J. \& Bullock, J.M. 2009. Can the pre-Neolithic provide suitable models for re-wilding the landscape in Britain? British Wildlife, 20, 5 (special supplement), 4-14.

Hodskinson, J. 1783. The County of Suffolk Surveyed, London. 
Kenworthy-Brown, J., Reid, P. Sayer, M., and Watkins, D. 1981. Burke's and Saville's Guide to Country Houses Vol. III: East Anglia, Burke's Peerage, London.

Kerridge, E. 1967. The Agricultural Revolution, Routledge, London.

Kirby, J. and Baker, A. 2013. The dynamics of pre-Neolithic European landscapes and their relevance to modern conservation. In I.D.Rotherham (ed.) Trees, Forested Landscapes and Grazing Animals, Routledge, London, 87-98.

Liddiard, R. and Sims, D. 2012. A hedgehog on the heath: the Second World War landscape of exercise 'Kruschen', Dunwich, Suffolk. The Archaeological Journal 169, 519-49.

Marrs, R.H., Hicks, M.J. \& Fuller, R.M. 1986. Losses of lowland heath through succession at four sites in Breckland, East Angli'. Biological Conservation 36, 19-38.

Mason, A. and Parry, J. 2010. The Warrens of Breckland: a survey by the Breckland Society, Thetford, the Breckland Society.

Monbiot, G. 2015. Feral: searching for enchantment on the frontiers of rewilding, Penguin, London.

Samojlik, T. and Kuijper, D. 2013. Grazed wood pasture versus browsed high forests: impact of ungulates on forest landscapes from the perspective of the Białowieża primeval forest. In I.D.Rotherham (ed.) Trees, Forested Landscapes and Grazing Animals: a European perspective on woodlands and grazed treescapes, Routledge, London, 143-161.

Sheail, J. 1971. Rabbits and Their History, David and Charles, Newton Abbot.

Soulé, M. and Noss, R. 1998. Rewilding and biodiversity: complementary goals for continental conservation. Wild Earth 8, 19 - 28.

Sussams, K. 1996. The Breckland Archaeological Survey: a characterisation of the archaeology and historic landscape of the Breckland Environmentally Sensitive Area, Suffolk County Council, Bury St Edmunds.

Taylor, C. 1972. The study of settlement patterns in pre-Saxon England. In P.J.Ucko, R.Tringham and G.W.Dimbleby (eds) Man, Settlement and Urbanism, Duckworth, London, 109-13.

Vera, F. 2002. Grazing Ecology and Forest History, Cabi, Wallingford.

Warde, P. and Williamson, T. 2014. Fuel supply and agriculture in post-medieval England. Agricultural History Review 62, 61-82.

Webb, N.R. 1998. The traditional management of European heathlands. Journal of Applied Ecology, 35, 987-990.

Williamson, T. 2007. Rabbits, Warrens and Archaeology, Tempus, Stroud.

Williamson, T. 2017. Grass, wood and water: approaches to the ecology of Brown's landscapes. In C.Hadley and I.D.Rotherham (eds) What Did Capability Brown do for Ecology? The legacy for biodiversity, landscapes and nature conservation, Wildtrack Publishing, Sheffield, 141-66.

Yalden, D. 2013. The post-glacial history of grazing animals in Europe. In I.D.Rotherham (ed.) Trees, Forested Landscapes and Grazing Animals: a European perspective on woodlands and grazed treescapes, Routledge, London, 62-9.

Young, A. 1804. General View of the Agriculture of the County of Norfolk, London.

\section{Contributors}

Tom Williamson is Professor of Landscape History at the University of East Anglia and has written widely on landscape archaeology, environmental history, and the history of landscape design. John Bumstead, Jayne Frost, Lynsey Owens and Steve Pease are volunteers at Suffolk Wildlife Trust's Knettishall Heath Nature Reserve, and have known the local landscape for many years. 


\section{Captions}

Figure 1. Knettishall Heath, as shown on the tithe award map of 1840 (above) and the first edition Ordnance Survey 6" of 1886 (below) (Courtesy Suffolk Record Office, Bury St Edmunds).

Figure 2. Aerial photograph of the heath as it is today (Google Earth).

Figure 3. A view across the nature reserve from the south-west, looking north (photo Tom Williamson).

Figure 4. Knettishall Heath: overall plan of principal earthworks (drawn by Tom Williamson).

Figure 5. Knettishall Heath: Second World War 'gun pits' and related earthworks (drawn by Tom Williamson).

Figure 6. 'Plough lines', exposed in the subsoil as a consequence of localised topsoil stripping. The lines, around $30 \mathrm{~cm}$ in width, the remains of 'furrows' are filled with ploughed-in dark organic matter, and are separated by strips of light, sandy soil around $40 \mathrm{~cm}$ wide (photo Tom Williamson).

Figure 7. Hut Hill (centre) and probable degraded barrow sites on Knettishall Heath (drawn by Tom Williamson).

Figure 8. The earthwork known as 'The Warren', Knettishall Heath, and related features (drawn by Tom Williamson).

Figure 9. Areas of probable disturbance on Knettishall Heath. Well over half the surface area of the heath has been affected by ploughing or mineral extraction (other symbols as on Figure 4) (drawn by Tom Williamson). 